\title{
姉弟に生じた鎖骨頭蓋異骨症の症例
}

\author{
竹内 靖・天笠 稔・本多善孝・松田登
}

\section{Cleidocranial dysplasia in a sister and brother}

\author{
Yasushi Takeuchi - Minoru Amagasa : Yoshitaka Honda - Noboru Matsuda
}

\begin{abstract}
Cleidocranial dysplasia is a form of congenital systemic bone dysplasia, that has such clinical characteristics as aplastic or hypoplastic clavicle bilaterally, delayed ossification of the skull, delayed deciduous dentition and jaw bone development. In Japan, many cases have been reported but relatively few in siblings or structural findings on teeth. We recently experienced cleidocranial dysostosis in an 18-year-old girl and her 16-year-old brother. We detected signs of intraoral abnormality and recorded histological findings related to extracted teeth.

Both cases showed hypoplastic development of the skull, upper jaw, clavicle, pelvis, and bones of the hand. The sister had 19 impacted teeth including 7 supernumerary teeth in her jaws. An impacted tooth extracted from the median upper jaw showed hypoplasia, namely enamellike tissues could be seen in the dentine, and there was very little cementum. Her brother had prolonged retention of the deciduous teeth and 28 impacted teeth including 10 supernumerary teeth. These impacted teeth were mainly seen in anterior teeth and premolars.

In examination of the family, their father was thought to have had similar physical features. Therefore it is assumed that a prepotent factor was transmitted to his children.
\end{abstract}

Key words: cleidocranial dysplasia (顉骨頭蓋異骨症), embedding teeth (埋伏米), hypoplasia of teeth (形成不全雨)

は じめに

鎖骨頭蓋異骨症は，鎖骨の欠損または形成不全，頭蓋 骨の骨化迋延，歯および顎骨の発有障害を特徵とする骨 系統疾患であり，1979年に先天性骨系統疾患国際命名法 により cleidocranial dysplasia と記载された ${ }^{1)}$ わが国 での報告例は百数十例汇達するが，同胞に生じた報告は 意外に少ない2 27)，著者らは姉弟に発生しした本症を経驗 し，その口腔症状と拔去した過剩埋伏幽を組織学的に検 討し， $2 ， 3$ の知見を得たので先人の報告例に追加する.

群馬大学医学部口腟外科学教室

（主任：松田 登教授)

Department of Oral Surgery, School of Medicine, Gunma University(Chief: Prof. Noboru Matsuda)

受付日：平成元年 4 月 14 日
症

例
症例 1

患 者：18歳 女性.

初 診：昭和61年 7 月回日。

主 訴：永久歯の萌出隄延.

家族歴：患者の母親 (48藏)には本疾患の所見はない。 父親（41歲）は永久雨の早期多数欠損があり，現在離別 中のため診査不能であるが，結婚当初より義域を装着し ていたとのことで，木疾患が疑われる。弟（16歳）は症 例 2 に示寸よらに本疾患に羅患しており，他に同胞はい ない。

既往歴：母親は妊娠中異常はなく，正常分姢で出生し た。出生時 $2,600 \mathrm{~g}$ で母乳で成有し，特記すべき全身的

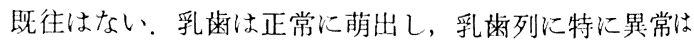
ないとのことであった。初潮は12歳時に認められた。

現病歴：永久潾の萌出逮延を主訴に昭和 61 年 7 月 


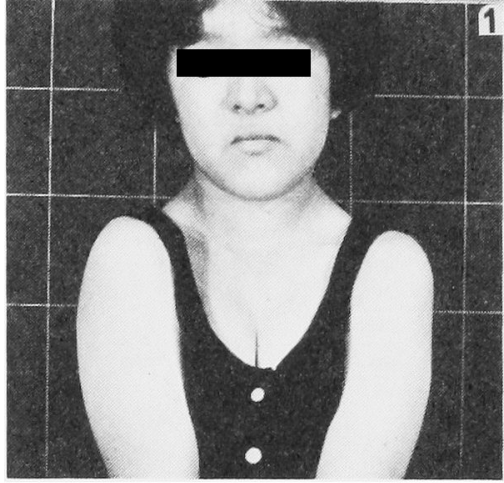

写真 1 初紩時における上半身の写真 （症例 1 ）

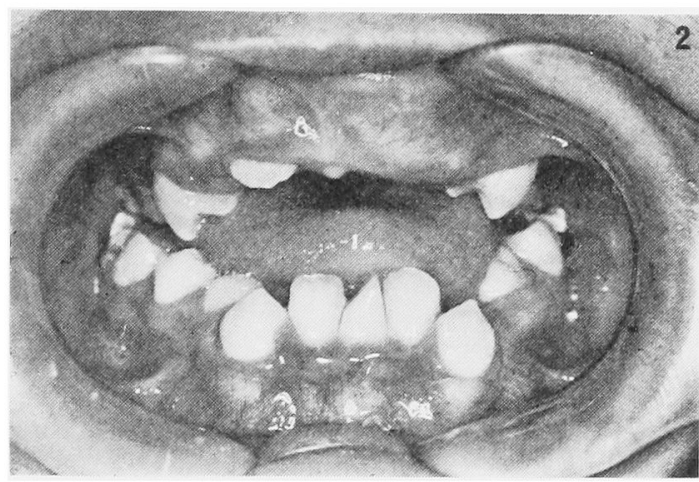

写真 2 初診時の口腔内（症例 1)

某歯科を受診し，X線写真上で多数歯の埋伏を指摘さ れ，当科を紹介され来院した。

\section{現 症}

全身所見：身長 $148 \mathrm{~cm}$, 体重 $44 \mathrm{~kg}$ ，体格は小柄で 頸部は幅広く，肩幅は狭く撫肩である，左側鎖骨は触知 できるが，右側鎖骨は不明膫で胸骨側では触れず，両側 の肩を前方で接近させることがでさる，上肢の運動障害 はなく，心肺の異常は認められなかった（写真1）。手 足の爪は小さく鈎状に警曲し，爪甲鉤彎症の所見を示し た。知能に異常はない.

顔 貌：前額部は広く突出し，前額正中部に陥凹があ り，陥凹は前頭桻合にそって頭頂に続いていた，䁷根部 は低く後退して扣り，内眼角間距離は $37 \mathrm{~mm}$ と広かっ た（写真１）.

口腔内所見 $: \frac{76542 \mid 467}{765431 \mid 123567}$ が萌出して扣り, 来 の大きさは正常の範用内にあると思われた。 移， 313 低位唇側転移， 1 捻転， 2 | 萌出不全など，歯列 不正があり，開咬执よび日歯部両側性交叉晈合の状態を 王していた(写真 2). 上顠の成長は悪く、口蓋は高く狭 くなっていた. 舌, 㐘肉, 顂などの粘膜は異常なかった。

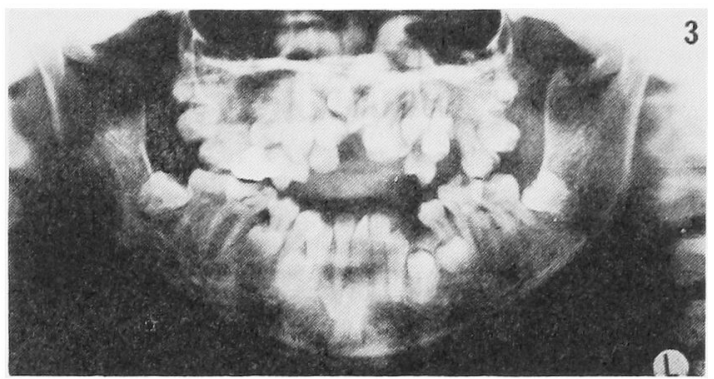

写真 3 初診時のパノラマX線写真（症例 1)

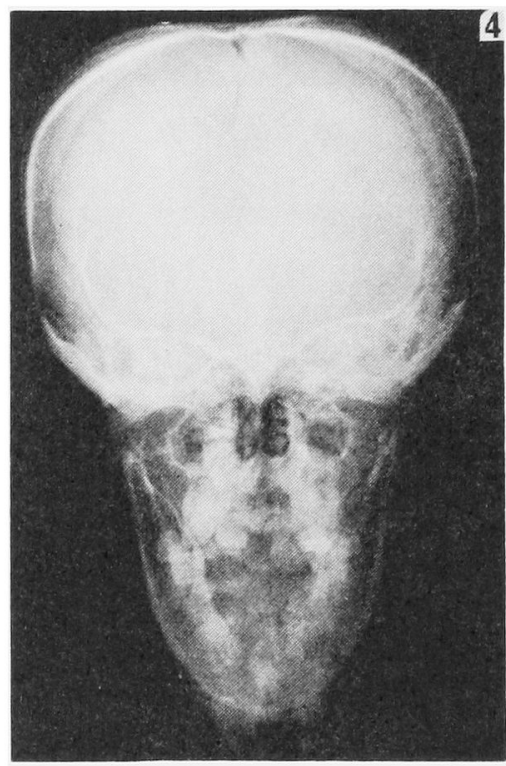

写真 4 頭部のX線写真（症例 1)

\section{$\mathbf{X}$ 線像}

(1) パノラマX線写真では，下顎枝は細く短く，下靧 角は鈍角に移行し，頓骨弓の形成は悪く，鼻腔底，上顎 洞底は上方に押し上げられていた。 上顠で 8 歯，下顎で

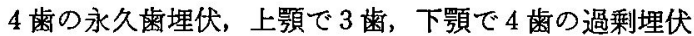
歯があり，埋伏崡の合計は19崡に達した。埋伏雪，過剩 埋伏畨とも主に前歯部，小曰歯部に生じ，過剩埋伏齿の 齿根桠い例が多く，一般に崡は丸みを带びているよう に思われた（写直了，图1）。

(2) 前額後頭撮影像では頭蓋泉門部に陷四があり, 頓 骨弓の発育は悪く，前頭洞はみられず，上買洞・鼻腔は 狭小化していた（写真 4 ）.

(3) 頭部X線規格写真による分析結果では，顔面角は 88 度と大きく，上䪽突出度はー13度で負に大きく，A-B 平面角は+8度であり，下顎前突を現した。 下顎下縁平 面角は36度で大きく，下類角は131 度と大きいので開咬 と判定された（表1）. 


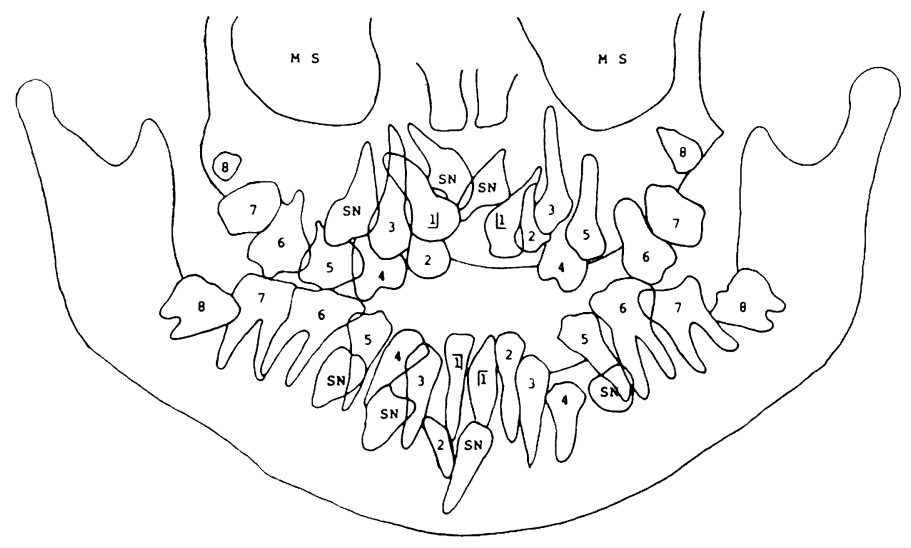

図 1 写真 3 の模式図

$\mathrm{SN}$ : 過剩埋伏畨

MS : 上顎洞

表 1 頭部X線規格写真分析表

\begin{tabular}{|c|c|c|c|}
\hline & Mean & S.D. & Deta \\
\hline Facial angle & 84.83 & 3.05 & 88 \\
\hline Convexily & 7.58 & 1. 95 & -13 \\
\hline$A-B$ plane & -1.81 & 3.50 & +8 \\
\hline Mandibular plane & 28.81 & 523 & 36 \\
\hline$Y-2 x i s$ & 65.38 & 5.63 & 65 \\
\hline Occlusal plane & 11.42 & 3.64 & \\
\hline Interincisal & 121.09 & 7.63 & \\
\hline$L-1$ to Occlussl & 23.84 & 5.28 & \\
\hline L-l to Mandibular & 96.33 & 5.78 & 63 \\
\hline$U-1$ 10 A-P plone & 8.92 & 1.88 & \\
\hline$F H$ to $S N$ plane & 6.19 & 2.83 & 22 \\
\hline SNA & 82.32 & 3.15 & 76 \\
\hline SNB & 78.90 & 3.15 & 87 \\
\hline SNA-SNB diff. & 3.39 & 1.77 & 11 \\
\hline$U-1$ to $N-P$ plone & 11.71 & 2.73 & \\
\hline$U-1$ to $\mathrm{FH}$ plane & 111,13 & 5.54 & \\
\hline$U-1$ to SN plane & 104.54 & 5.55 & \\
\hline Gonial angle & 122.23 & 4.61 & 131 \\
\hline Ramus inclination & 2.93 & 2.93 & 6 \\
\hline
\end{tabular}

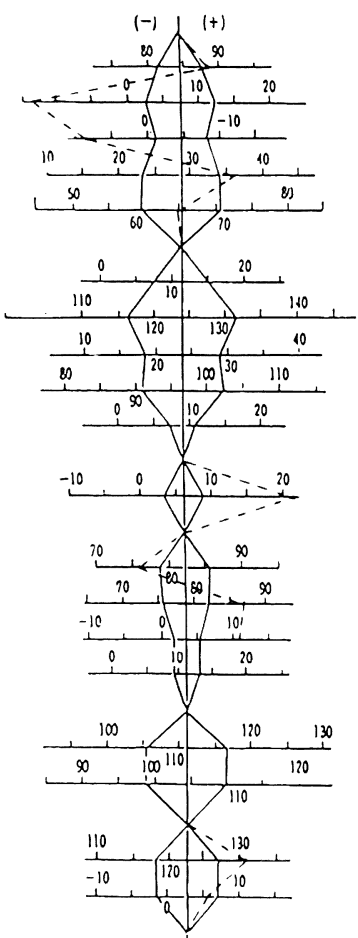

(4) 胸部揖よび苻椎X線像で，左側鎖骨は認められる が右側鎖骨は胸骨側 $2 / 3$ が欠如し，胸郭は釣鐘状を呈し ていた。肩甲骨は下方に 位置し，鳥口突起の発育は悪 い.上部胸椎の潜在 2 分准椎裂があり, 軽度の存椎側智 を呈していた（写真 5 ).

(5)骨般のX線像では，恥骨結合は離開し大腿骨頸部
は短縮しているが，仙腸関節は正常であった（写真 6). (6) 手のX線像では，手根骨による骨年龄は正常の範 囲内にあるが，中手骨は第 1 指から第 5 指まで細くかつ 長く，基節骨も第 2 指から第 5 指まで細かった。 また中 節骨は第 2 指および第 5 指が短縮し，第 2 ，第 3 指では 細かった（写真 7 ）。 


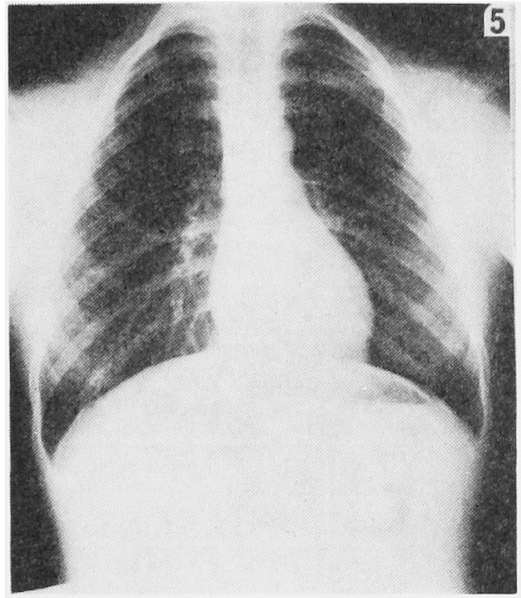

写真 5 眴部X線像（症例 1）

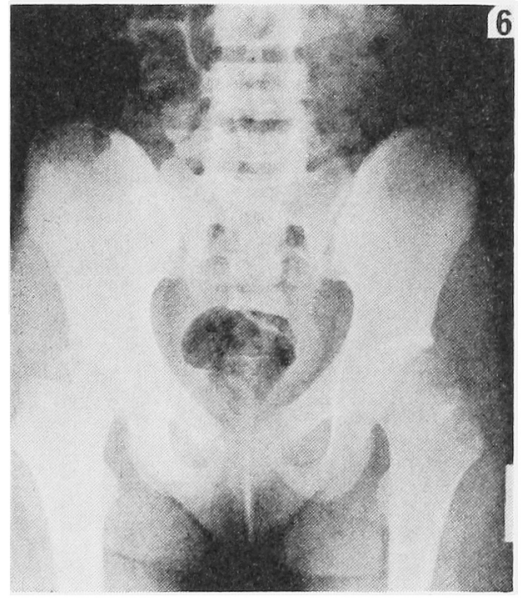

写真 6 骨盤X線像（症例 1 ）

臨床検査および染色体険査成績 : 成長 ホルモン，11deoxycortisol. 11-OHCS, 血中カルシウム，無機りン， 末梢血液像には特別な所見はなかった。染色体の検索に おいても, その数, 形態に異常はなかった（写真 $8 \mathrm{~A}$ ).

処置と䅅過：昭和61年 8 月曰日，上靧前画部の開空を 行い半年間経過をみていたが，萌出傾向がなかったので 積極的な矯正治療を要すると判断した（写真 9). しか し, 知正治潦を希望しなかったので補緅処置を行らこと にし，過剩歯扣よび低位雪を抜雨したが，その後，患者 は処䈯を中断している。

抜去した上頱正中過剩埋伏歯の組織像 : 研磨標本では 象牙質内にエナメル質様の組織が存在し，またエナメル 質の一部に形成不全方諗められた（写真 $10 \mathrm{~A}$ ). 同部の マイクロラシオグラムでは(ソフテックス, $30 \mathrm{~mA}, 2$ 秒で撮影)，象牙質内のエナメル質様の部分はエナメル

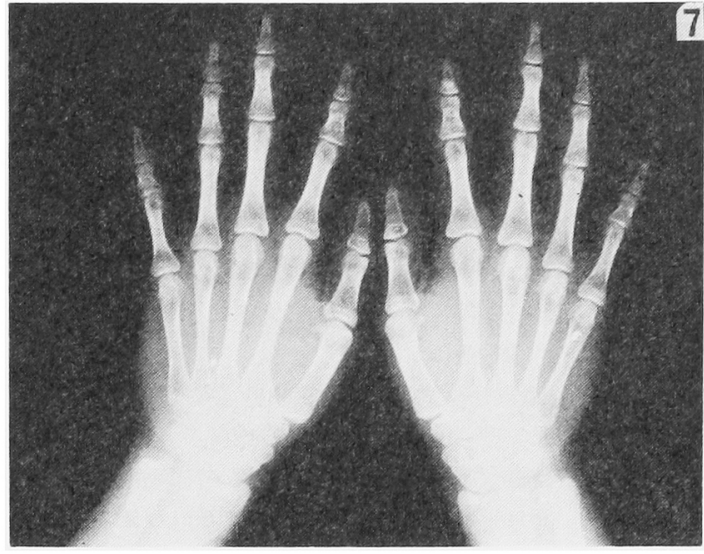

写真 7 手の $\mathbf{X}$ 線像 (症例 1 )

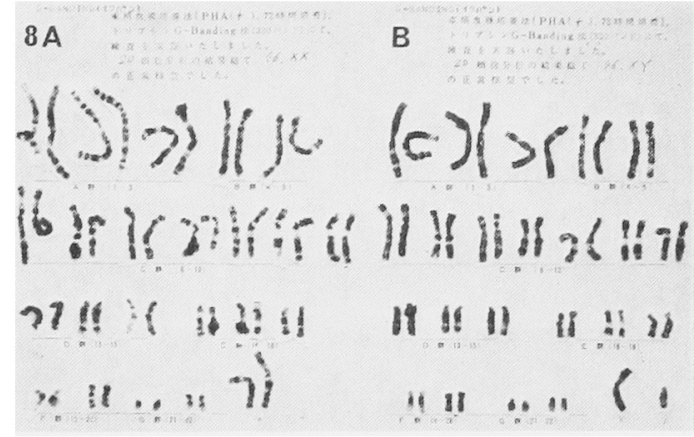

写真 8 染色体の分析 $\mathrm{A}$ : 症例 $1, \mathrm{~B}:$ 症例 2

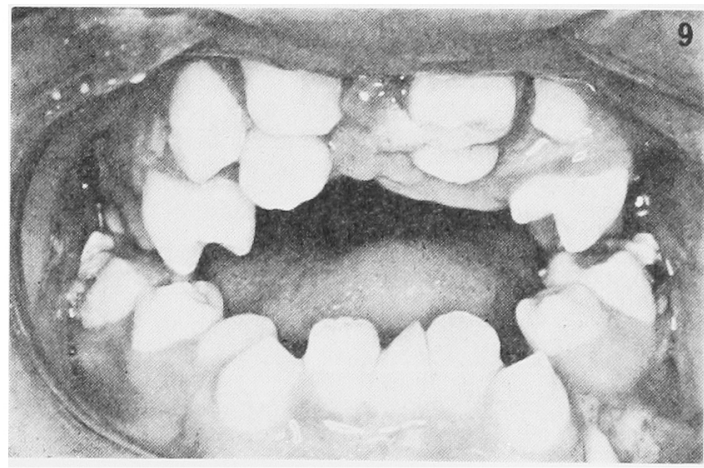

写真 9 開空後の口腔内（症例 $1 ， 61$ 年 8 月曰日）

質と同じX線不透過像を示し，エナメル質と推定され た（写真 $11 \mathbf{A}$ ). この異所性エナメル質周囲の象牙細管 は同心円状の配列を示した（写真 11B）。歯根部のセx ント質の形成不全もみられた（写真10A， B ）.

症 例 2

患 者: 16歳 男性. 
初 診: 昭和61年 8 月日.

主 訴：永久の萌出遅姃.

家族歴 : 症例 1 の弟である.

既往歴：母親が軽度の妊娠中毒に罹患したが，特に処 置を受けず佂常に出産した。出生時 $3,200 \mathrm{~g}$ で母乳と 人工乳で成育した，乳歯萌出は巽常なく，現在まで特に 全身的既往はない。

現病歴：旅が当科を受診し，家族歷炕より本疾患が寲 われたので来院した。

現 症

全身所見：身長 $161 \mathrm{~cm}$ ，体重 $41 \mathrm{~kg}$ ，小柄で頸部の 幅は広く，撫肩で両側の鎖骨は胸骨側では触知されず， 左右の肩を前方で接近させることができた（写直 12）. 手足の爪は小さく爪甲鉤督症を呈していた，知能洪常 はない。

顔 貌：症例 1 と同棣に, 前額部の突出, 内眼角間距 離の開大などがみられた。

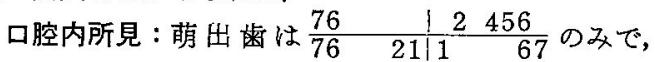

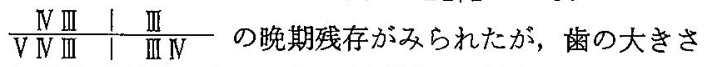
には特に異常はなかった。位捻転，卢捻転と口蓋側転 䔟, $\overline{2 \mid 1}$ 捻転など歯列は不正であり，右側曰歯では側方 交叉咬合の状態を呈していた。 その他, 開咬, 上箱の劣 成長があり，口蓋は高く狭くなっていた（写真 13），口 貯粘膜には異常所見はなかった。

$\mathbf{X}$ 線像

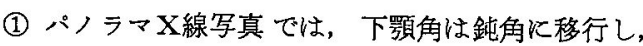
下靧枝は比較的細長かった。埋伏歯の合計は 28 歯を数

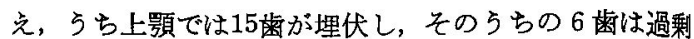
埋伏歯であり，一方，下䫇では13菊が埋伏し，5ち4齿 は過剩埋伏歯であった。これらは前歯部に5歯，小四歯 部に 5 歯観察された。過剩埋伏齿の形は症例 1 亿類似
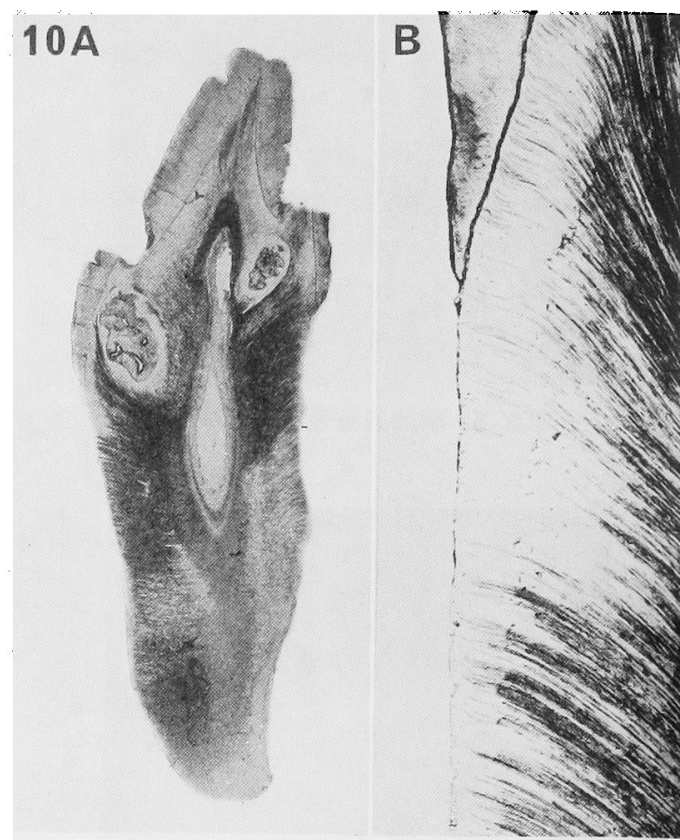

写真 10 上顎正中過剩埋伏菌の組織像（研磨標本） $(A: \times 35, B: \times 220)$

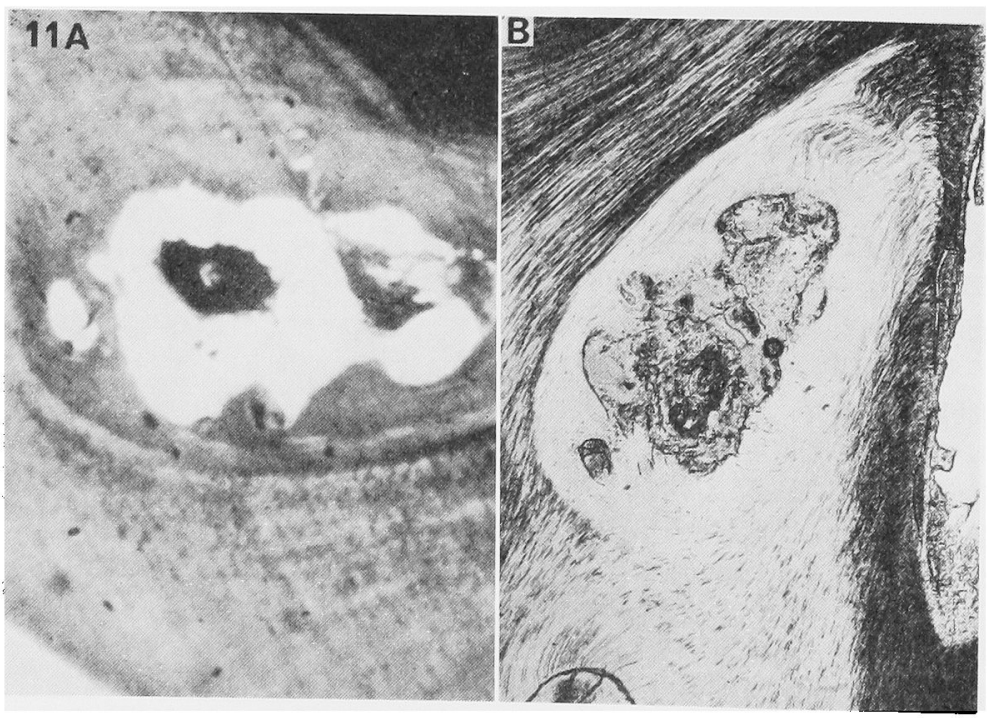

写真 11 象牙筫内のエナメル質様組織

A : マイクロラジオグム $\times 220$

$\mathrm{B}$ : 研磨標本 $\times 220$ 


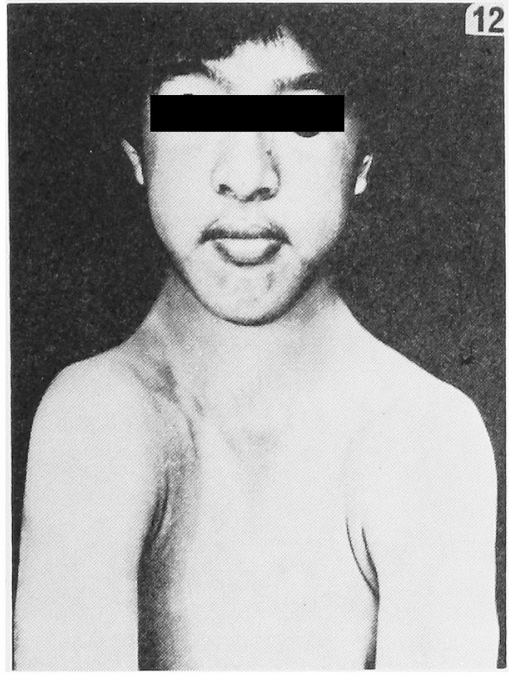

写真 12 初診時における上半身の写 真 (症例 2)

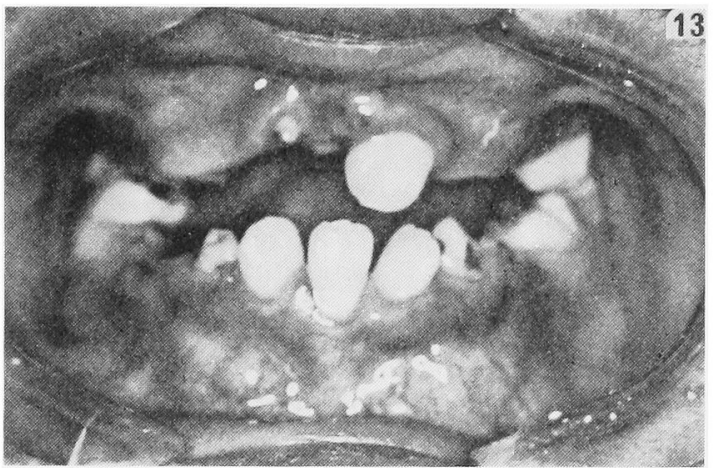

写真 13 初衫時の口腔内（症例 2)
し，菌根部は短く，歯は丸みを带びていた（写真14, 図 2).

(2) 前額後頭撮影像では，頭蓋骨は矢状縫合の癒合不 全が荡り，頓骨弓の発育は悪く，前頭洞はみられず，上 靧洞，鼻腔は狭小化していた（写真15）。

(3) 胸部执よび脊椎X線像は，胸部は釣鐘状で有甲骨 は小さく鳥口突起の発育が悪く、鎖骨は両側とも肩峰側 で痕跡状となり，上部胸椎は潜在性 2 分金椎裂を呈して いた（写真16）.

(4)骨盤括よび手のX線像は，恥骨結合離開や大腿骨 頸部短縮も症例 1 と同様である。手根骨による骨年路は 正常であるが，中手骨では第 2 指，第 5 指が細長く，第 3 指，第 4 指の基節骨は細く，末節骨はすべて短縮して いた。

臨床検查および染色体検査成績 : アルカリフォスフォ ターゼの活性度がわずかに增加していた以外には，成長 ホルモン，11-deoxycortisol，11-OHCS，血清カルシウ ム，無機リン，末梢血夜像には異常はなかった。染色体 の数，形態とも正常であった（写真 $8 \mathbf{B}$ ).

処置と経過：昭和61年 8 月日日, 残存乳歯の技齿と上

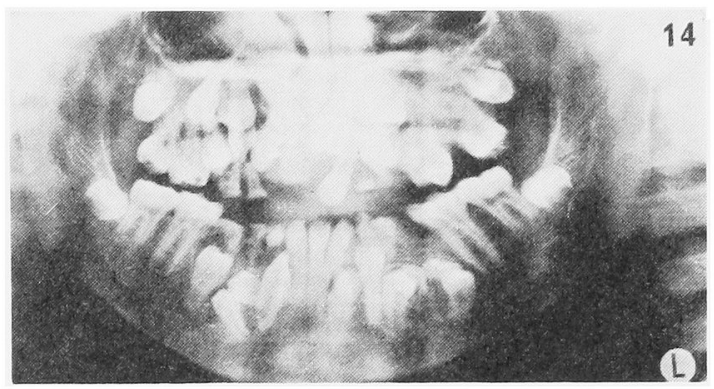

写真 14 初診時のパノラマX線写真（症例 2)

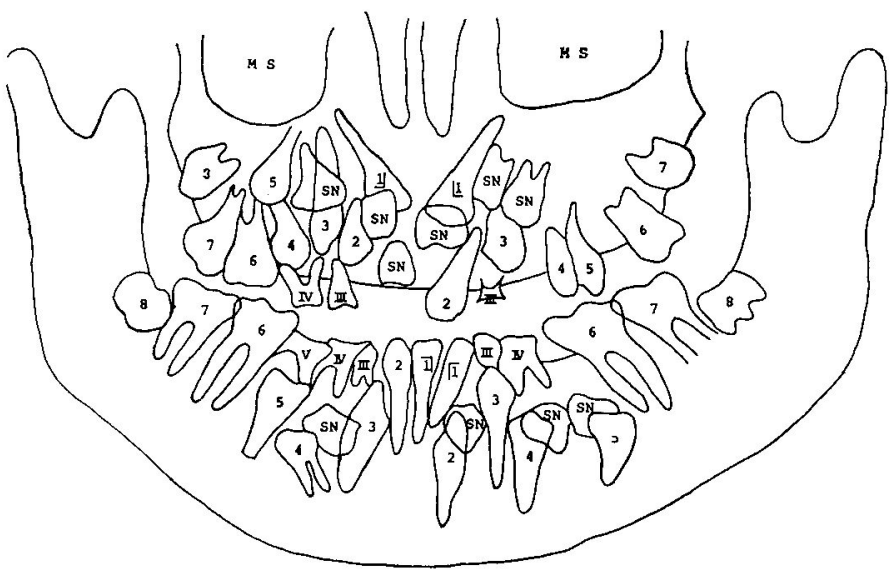

図 2 写真14の模式図

$\mathrm{SN}$ : 過剩埋伏曾

MS : 上顎洞 


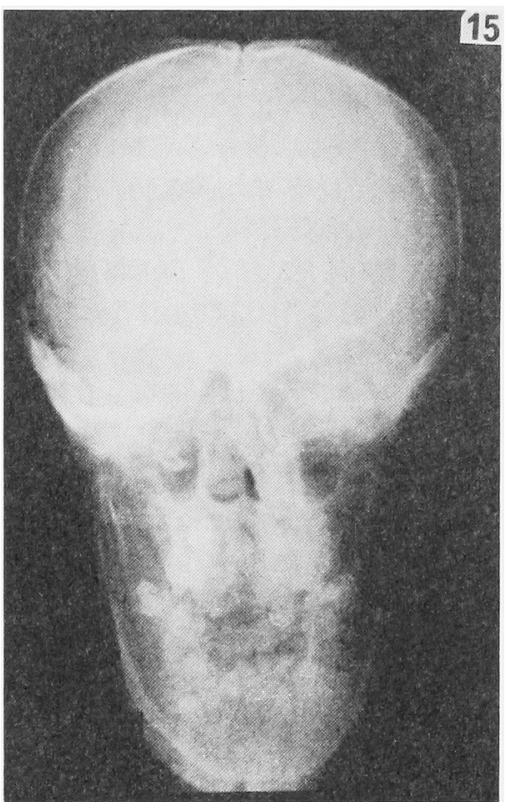

写真 15 頭部X線写真（症例 2）

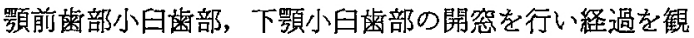
察中である．開空時の骨生検の組緎像では，特記すべき 異常所見はなかった，開空後，萌出傾向がないので，矯 正治療と補緅処置を考虑中である。

考察

本症の患者は，一般に小柄で無肩で頸は長く，奥骨と 上顎骨の発育不全のため鼻根部は広く奥背は凹み，前頭 および側頭部が韭り出し幼罗様の顔貌を呈する。鎖骨は 両側性または片側性に欠如するか，または形成はきわめ て悪く，そのため左右の肩を答せ合らことができる，頭 蓋骨の形成も悪く，大泉門，上買洞に異常を生じ，その ほか骨盤，冹柱，手根骨や足根骨の発育遅延ないし変形 をみることがある

本症例の姉, 弟とも症例の項で記したように, 舆肩で 頸は長く，悬根部は広く，左右の肩を近づけることがで きたまた，X線像で鎖骨，頭蓋骨の形成不全のみなら ず，骨盤，资柱，手指骨の発育僬延ないし変形があり， 特徴ある本症の所見を備えていた。

頭部X線規格写真による顔面の計測では，中顔面領域 の発育不全に起因する下顠前突を伴らことはよく知られ ている ${ }^{2,12,13)}$ ，姉の症例の分析結果，顔面角，A-B 平面

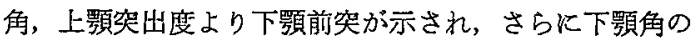
開大による開咬を是し，本症の特徽的な所胃を現した。

Hesse $^{14)}$ により最初に報告された蔽の所見，すなわち 1）埋伏菌が存在する，2）埋伏曾性傾斜し深部に存在

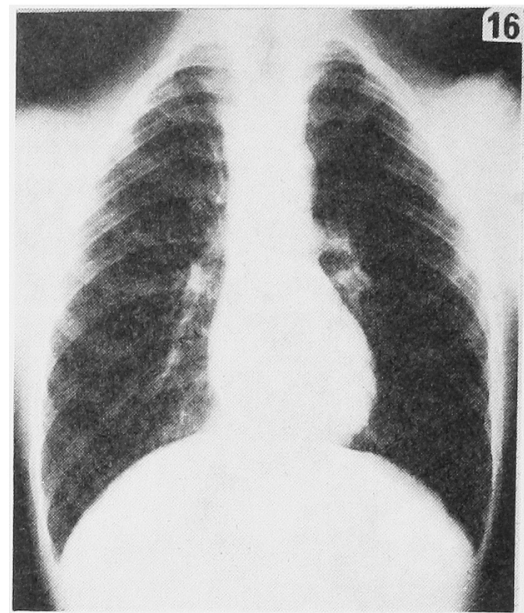

写真 16 胸部 $\mathrm{X}$ 線像 (症例 2)

する，3）荬の形態と数の異常がある，4）乳雪は長期 残存し，骨植堅固で歯根の吸収はない５）上顎骨の発 育不全に伴う下顎前突がある，は本症の注目すへきき所見 の1つである，埋伏幽の多くは小曰歯部や切雨部に起こ

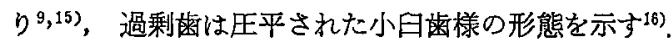

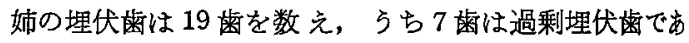
り, 弟の埋伏雪は28歯, らち過剩埋伏菌は10畨に達し, 大部分が前歯，小曰歯部に認められた。萌出歯名位置の 異常が多く，過剩埋伏齿は崡根が短く，歯の外形は丸み を骶びていた。

本症の過剩歯あるいは埋伏雪の組織像の報告は少な い. Anderson ${ }^{17)}$, Smith $5^{18)}$, Gundlach $5^{19)}$, 䁆田 $ら^{15)}$ は，第 1 セメント質（無細胞セメント質）は齿根の 全層にみられるが第 2 セメント質（有細胞セメント質） は欠如し, Rushton ${ }^{20)}$ ，Hitchin ${ }^{21)}$ 第 2 セメント質の欠 如を認め，本矤患の特徵的な所見であると記した。 しか し，本ら ${ }^{22)}$ は過剩埋伏雨は第 2 セメント質が少なく， 一万，萌出過剰荬ではセメント質の異常はなく，その理 由として第 2 セメント質は勗嚼機能と深い関連があるの で，萌出過剩画では第 2 セメント質の異常を生しないと 推測した。，さらに萠出過剩歯の 1 本に，象牙質と歯骮加 2 分された明らかな形成異常を恐めた。北村ら ${ }^{23)}$ は肉腿 的観察ではあるが，抜去した小罡部埋伏歯に，咬合面 形態の不整とエナメル質の一部が久如し，そのため象牙 質が露出している像を見い出した。

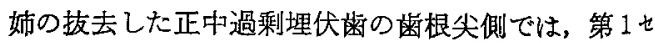
メント質はみられるものの棶頸部に近い部位の第 1 セメ ント質は久如し，全層にわたり第 2 セント質は確認て きなかった，高木ら 24 も抜去乳畨ではあるが，本症例と 同様に第 2 セメント質が欠如し，第 1 セメント質に㪊 成不全を認めている，本症例では，さらにエナメル質が 一部欠如し，象牙質内にエナメル質様の組織が含まれ， 
形成異常歯と判定された。このような形成異常歯の報告 はないよらであるが, 今後さらに米の組織像の検索が追 加されれば, 本症例と同様の所見も検出されると期待し ている。

本症の原因は不明であるが，欧米では約半数が優性遺 层によると記されている25) わが国では遺伝関係のあき らかな症例はこれよりも少なく, 下里ら ${ }^{26)}$ は $10 \%$, 龟田 ら ${ }^{15)}$ は19.7\%であると述べているが，わが国では遗伝疾 患の家族歴を詳細に調べることはむずかしく，実際の発 現率はこれらの報告よりも高いはずである。自然発症に みえる例では新しい突然変異によるか, 浸透率の低い遗 伝子が関与寸ると考劣られ(0), 遗伝性と本症の係わりの 深いことが示唆されている.

自験例では同胞に生じており，父親に本症が寲われ， 父親を介しての優性遺伝の可能性が推測された。染色体 検査の報告は異常のない症例が多く2,5,27), 本症例でも その数, 形態に異常がなかったので, 染色体異常との関 係は否定的と考えられる。

鎖骨頭蓋異骨症では，全身の骨格の異常は日常生活に 支障がないので積極的な処置は行われていない. 歯科領 域では咀嚼機能のみならず審美性にも障害をきたすの で，種々の治療方法がなされているが，義荬による補綴 と矯正治療が主体となっている。しかし，埋伏歯がきわ めて多い場合や，著しい顎変形症を伴う症例の治療は困 難で, Miller $5^{28)}$, 梶ら ${ }^{29)}$ が指摘しているよらに, 補 綴, 口腔外科, 矯正, 小昌歯科による総合的処置が肝要 と考えられる。

本症例では, 姉, 弟とも埋伏雪を開空し, 次いで矯正 治療を予定していたが，姉は希望しなかったので過剩粀 と低位霜を抜去し引き続き局部義歯の装着を，弟には矯 正治療と補緅処置を予定している.

\section{ま と め}

18歳の姉，16歳の弟に発現した鎖骨頭蓋異骨症を経験 した。本症の特改である頭蓋骨，上顎骨，鎖骨，骨盤な どの形成不全と, 姉では埋伏歯は19齿を数え（うち7粦 は過剩埋(伏齿)，抜去した上顎正中過剩埋伏歯は形成不 全歯で象牙質中にエナメル質様の組織が含まれ，セメン ト質形成不全も認められた。弟は乳米の晚期残存と, 埋 伏歯は28歯に達し, 弓ち10米は過剰埋伏歯であった。

本論文の要旨は昭和63年 6 月第 141 回日本口腔外科学 会関東地方会で報告した。 全身の骨格系の所見について ご教示をいただいた本学整形外科学教室 鎌田真彦先生 に深謝する。

\section{引用文 献}

1) 渡辺健, 杉浦保夫: Cleidocranial dysplasia 一 3 代10名に発症した 1 家系報告とその遗伝的 考察. 臨整外 17：1245-1254 1982.

2）落合靖一，浅野秀明，他：鎖骨頭蓋異骨症の遗 伝学的研究。小児料誌 1：82-85 1963.

3) 野本泰正, 土屋惠一, 他: Cleidocranial dysostosis の姉妹（抄）。小児科䛦療 43：674 1980 .

4）宮野前健, 吉光千記, 他：鎖肛をはじ種々 の合併症を伴った Cleidocranial dysostosis の 兄姉例（抄）。日小児会誌 84：297 1980 .

5）合科慧治，武田進，他・家族的に2られた Cleidocranial dysostosis. 口科誌 27：123-131 1978.

6）金沢治樹, 宮沢政義, 他：䠝骨頭蓋異骨症の 1 例 (抄). 口科誌 33: 1641984 .

7）逍 豊照, 日高亮，他：兄姉ならびに父親に 現われた鎖骨頭蓋異形成症について，近東稪正 誌 19: 107-121 1984.

8) Gorlin, R.J. and Pindborg, J.: Syndromes of the head and neck. 1 st Ed, McGraw Hill Co, New York-Toronto-London, 1964, p 138145.

9) Kalliala, E. and Taskinen, P.J: Cleidocranial dysostosis. Report of six typical cases and one atypical case. Oral Surg 15: 808-822 1962.

10) 石川梧朗, 秋吉正豊：口腔病理学 II. 改訂版, 永末書店, 京都, 1982, 273-275頁。

11) Gorlin, R.J. and Goldman, H.W.: Thoma's oral pathology Vol. 1, 6 th Ed, C.V. Mosby Co, St Louis, 1970, p 534-536.

12）園山昇, 佐藤田鹤子, 他: Dysostosis cleidocranialis の1例について。 日外誌 23：267272, 1977.

13) 水野智之, 北島晴比古, 他: 多数の埋伏歯を伴 った鎖骨頭蓋骨異形成症の 1 例。日口外誌 29 : 2333-2341 1983.

14) Hesse, G.: Weitere Befunde am Zahnsystem dysostoischer Individuen. Ztschr Stomatol 24: 205-218 1926.

15）亀田明秀, 野村寿男, 他：鎖骨頭蓋異骨症の 1 例。口科誌 29: 483-492 1980 .

16) Hopkins, R.. Cleidocranial dysostosis. A case report. Br. J Oral Surg 17: 232-243 1979.

17) Anderson, N.H.H.: A histologic study of cementum in a case of cleidocranial dysostosis. Oral Surg 25: 470-478 1968.

18) Smith, N.H.H. and Sydney, N.S.W.: A histologic study of cementum in a case of cleidocranial dysostosis. Oral Surg 25: 470-478 1968.

19) Gundlach, K.K.H. and Buurman, R.: Dysplasia cleidoclanialis-Histologische Befunde am 
Zahnzement. Dtsch Zahnärztl Z 33: 574-578 1978.

20) Rushton, M.A.: An anomaly of cementum in cleidocranial dysostosis. Brit Dent J 7: 81-83 1956.

21) Hitchin, A.D.: Cementum and other root abnormalities of permanent teeth in cleidocranial dysostosis. Brit Dent J 21: 313-318 1975.

22）森本啓三，木原昭裕，他：鎖骨頭蓋異骨症一特 に過剩迷の組織所見について. 補綴誌 31：6186241980.

23）北村公史郎, 杉本克美, 他: 多数の埋伏歯を有 する鎖骨頭蓋異骨症の 1 例. 日口外誌 31：3193241985.

24）高木 慎, 長畠駿一郎, 他：乳歯のセメント質
形成不全を伴った鎖骨頭蓋異骨症の 1 例。口科 誌 36: 208-218 1987.

25) Soul, A.B.: Mutational dysostosis (Cleidocranial dysostosis). J Bone and Joint Surg 28: 81-102 1946.

26) 下里常弘, 待田順治, 他: Dysostosis cleidocranialis の 1 例. 口科誌 16: 348-360, 1967.

27）渡辺 熙, 玉川輝明, 他: 鎖骨頭蓋形成不全症 (Cleidocranial dysostosis) の 3 例. 脳と発達 14: 71-76 1982.

28) Miller, R., Sakamoto, E., et al.: Cleidocranial dysostosis: a multidisciplinary approach to treatment. JADA 96: 296-300 1978.

29）暒 隆一, 連 利隆, 他 : 鎖骨頭蓋異骨症の 1 例。日口外誌 27: 90-101 1981 . 